\title{
Growth in human population and consumption both need to be addressed to reach an ecologically sustainable future.
}

\author{
Elias Ganivet
}

Independent scholar, 64100 Bayonne, France.

\begin{abstract}
Nowadays, human activities are causing an important collapse in global biodiversity while also affecting the global climate considerably. Despite historical agreements on both biodiversity conservation and climate change, humanity keeps changing the face of the planet at an increasing rate. An undisputed factor in global change is the excessive and growing human consumption. On the other hand, it seems that linking humanity's environmental impact with population growth has been quite controversial in the international debate, as if, somehow, biodiversity loss and climate change were unconnected to it. To this purpose, this paper reviews (1) the impacts of continuing human population growth on global biodiversity and climate through the examples of food and energy production, (2) changing perceptions about population growth and (3) the potential solutions that could be used to address this issue. Despite not the only factor, the research reviewed in this paper highlights that continuing population growth plays a substantial global role in the destruction of biodiversity and in climate change, and this role urgently needs more attention in scientific, policy and public circles. Both unsustainable population levels and excessive consumption are part of the equation and must be addressed concurrently in developing and developed countries. Several non-coercive strategies are possible to address the population question, mostly through access to education and contraception, in order to empower women through the basic human right to have children by choice. In any case, although limiting population growth may not be the only solution required to fix current environmental problems, ignoring it is likely to hinder any ecologically sustainable future.
\end{abstract}

Keywords: Biodiversity loss; Climate change; Excessive consumption; Population growth; Sustainability

\section{Introduction}

Two decades ago, ecologist Peter Vitousek already stated that "we are the first generation with tools to understand changes in the Earth's systems caused by human activity, and the last with the opportunity to influence the course of many of these changes" (Daily 1999). More than ever, humanity is changing the face of the planet at an increasing rate, conducting to an unprecedented "environmental breakdown" (Laybourn-Langton et al. 2019). While a century ago only $15 \%$ of the Earth's surface was modified by the direct effects of human 
activities (Klein Goldewijk et al. 2011), this proportion has now grown to $87 \%$ of the ocean and $77 \%$ of the land (Watson et al. 2018). This has led to a global collapse of biodiversity with, between 1970 and 2014, an average $60 \%$ decline in populations of all vertebrate species (measured by the Living Planet Index), and up to $83 \%$ for freshwater species alone (WWF 2018). Arthropods biomass also declined by more than $75 \%$ over the last 30 years in some regions (e.g. Hallmann et al. 2017; Lister and Garcia 2018; Sánchez-Bayo and Wyckhuys 2019), disrupting entire food webs (e.g. birds, MNHN 2018). According a recent report from the Intergovernmental Science-Policy Platform on Biodiversity and Ecosystem Services (IPBES), human activities threaten around 1 million species with extinction (IPBES 2019), many others being extinct already (Baillie and Cokeliss 2004; IUCN 2018). Considering this rapid loss of biodiversity, the world is now facing a sixth mass extinction (Ceballos et al. 2010; 2015, 2017), the first to be caused by a species - Homo sapiens.

In addition, since the last century, human activities have also led to $\sim 0.9{ }^{\circ} \mathrm{C}$ of global warming due to continuously increasing greenhouse gas (GHG) emissions ( 584.4 GtC emitted from 1860 to 2014 , Mora et al. 2018a) from fossil fuel combustion (Hansen et al. 2013), industry processes and agricultural production (Ripple et al. 2014). Without reduction of these emissions, current projections predict drastic changes in the global climate, including (1) changing temperature and precipitation patterns, (2) shifting frequencies and intensities of extreme weather events (e.g. droughts, heatwaves, storms, floods), (3) altered patterns of weather systems (e.g. El Niño, monsoon) and (4) sea-level rises (IPCC 2012, 2013), among others. These changes are expected, as soon as 2030, to lead to climates not experienced on Earth since the Pliocene, 3 million years ago (Burke et al. 2018), which is likely to profoundly affect the whole biosphere. As a consequence, current high rates of biodiversity loss are expected to accelerate even more in the next decades (Thomas et al. 2004; Cahill et al. 2013; Huntingford et al. 2013; Moritz and Agudo 2013; Urban 2015).

Yet, as part of the natural world too, humans will also be inevitably affected by both biodiversity loss and climate change. The last National Climate Assessment illustrated well how such consequences are already playing out in North America (USGCRP 2018). Mora et al. (2018b) also reported evidence for 467 pathways by which human health, economy, infrastructure, water, food and security have been recently impacted by climate hazards. The last few years have shown good examples of extreme weather events, such as storms, heatwaves, droughts, fires, intense precipitations and floods. Mora et al. (2018b) warned that humanity is highly vulnerable to these cumulative climate hazards as they will be intensified if GHG emissions are not aggressively reduced. In addition, beside the intrinsic value of the natural world - that has a right to exist for itself - nature is also essential for supporting human life considering its contribution to people (e.g. clean water, food, climate 
regulation, Díaz et al. 2018). Recent reports warned that the continuous decline of biodiversity and nature's contributions also seriously endangers economies, the security of the world's food supplies and the livelihoods of millions of people (IPBES 2018; FAO 2019). Therefore, addressing these environmental problems is urgently needed to ensure a better and safer future for both humans and the rest of the natural world (Berry 2000; Daily et al. 2009; Ceballos et al. 2010; Crist et al. 2017).

Over the last decades, both climate change and biodiversity loss have been key issues discussed internationally (e.g. UNCED 1992). In 2010, during the Tenth Conference of the Parties (COP 10) to the Convention on Biological Diversity, 193 nations agreed to reach 20 objectives related to the conservation of biodiversity by 2020 (Aichi Targets, CBD 2010). Among others, they included reducing by half the loss of natural habitats and the creation of more efficient protected areas worldwide. Similarly, under the December 2015 Paris Agreement, reached during the COP 21 on climate change, 195 nations agreed to limit the global average temperature increase by 1.5 to $2{ }^{\circ} \mathrm{C}$ above pre-industrial levels (UNFCCC 2015). However, despite these historical agreements, given increasing human population and consumption (Raupach et al. 2007) as well as a lack of political will (Kemp 2017; Custer et al. 2018), addressing these issues is regarded as a very difficult challenge (Mora et al. 2018a; Pinheiro et al. 2018). In November 2018, during the COP 14 to the Convention on Biological Diversity, it emerged that almost none of the Aichi Targets will be reached by 2020. Even worse, habitat degradation is increasing, with record tropical forest losses in 2017-2018 (GFW 2018; INPE 2018). In addition, 2018 was a record year in GHG emissions (Le Quéré et al. 2018). In order to reach the $2{ }^{\circ} \mathrm{C}$ objective from the Paris agreement, current efforts must be tripled by 2030 (UNEP 2018). Otherwise, global warming of about $3^{\circ} \mathrm{C}$ is to expect by 2100, with warming continuing afterwards (IPCC 2018).

In this context, one question remains: "what can be done to reverse this trend"? Although some sceptics may still object, even when considering the current situation (Shao 2018), most of the scientific community agrees that biodiversity loss and climate change are direct consequences of human impacts on Earth. Undeniably, a major factor is humanity's overconsumption, at the centre of international concerns for a long time already. Humanity is using the planet excessively both as a source (e.g. lands, resources) and sink (e.g. pollution, waste). Many innovative solutions and improvements in technologies are developed worldwide in order to address this excessive consumption and reduce humanity's footprint. Unfortunately, with a world population increasing annually by about 82 million people (United Nations 2019), it is very difficult to keep up. For this reason, Dietz and O'Neill (2013) stated that "we need smaller footprints, but we also need fewer feet". Generally credited to Ehrlich and Holdren (1971, 1972), environmental impact was also described as the product of population, 
affluence (i.e. lifestyle, per-capita consumption) and technology (cf. IPAT Equation, Chertow 2000). Yet, linking sustainability with population growth has been quite controversial in the international debate, and relatively neglected over the last 2-3 decades (Meffe 1994; Potts 2009; Mora 2014), as if, somehow, humanity's environmental impact was unconnected to it.

Changing our approach is needed if we are to avoid the likely extinction of two-thirds of life by 2100 (Raven et al. 2011). As already noted by Hulme (2009), if there is a "safe" limit to avoid for climate change, "is there not also a desirable world population?" Undeniably, indefinite growth of both population and consumption is impossible on a planet with finite space and resources. In fact, meeting the UN Sustainable Development Goals is already regarded as requiring a lower world population growth (Abel et al. 2016; United Nations 2019). The International Panel on Climate Change (IPCC) also recently stated that GHG emissions could be lowered by $30 \%$ by 2100 if access to contraception was provided for women expressing a need for it (Smith et al. 2014). In 2017, over 15,000 scientists from all over the world also reported in a "warning to humanity" that population growth needed to be addressed otherwise all efforts to reach a sustainable future would be in vain (Ripple et al. 2017). This outlines the need to bring population growth to the forefront of international concerns and overcome the taboos around this question. Yet, until recently, the topic remained relatively poorly documented and too many people, in scientific, policy and public arenas keep ignoring or denying that population growth is also an issue.

In that context, this paper aims to support the most recent studies that highlighted the need to address both overconsumption and population growth if we are to reach an ecologically sustainable future (e.g. Guillebaud 2016; Kopnina and Washington 2016; Crist et al. 2017; Gil Pérez and Vilches 2017). To this purpose, this paper reviews (1) the impacts of continuing human population growth on global biodiversity and climate through the examples of food and energy production, (2) changing perceptions about population growth and (3) the potential solutions that could be used to address this issue. Although this paper does not bring a completely new perspective regarding this topic, another overview of current literature will hopefully contribute to raising scientific, political and public awareness that any attempt to stabilize or lower our population, through noncoercive measures, is a good strategy for reducing overconsumption on all fronts.

\section{Impacts of a growing human population on global biodiversity and climate}

Interestingly, the concerns about a continuously growing human population are not something new. More than two hundred years ago, Malthus (1798) already noted that human population was increasing faster than the 
resources necessary for subsistence and postulated that this might become an issue in the future. Nevertheless, Malthus underemphasised the increase in technologies, especially in agriculture (i.e. Green Revolution), that occurred during the twentieth century and enabled humanity to produce a large amount of food, making possible a population explosion. From 1 billion around 1830, the human population had increased to about 2.5 billion by 1950 and is now approaching 8 billion (Fig. 1). However, providing resources, especially food, for such a large number of people has inevitably led to significant environmental impacts, affecting every ecosystem of the planet (Crist et al. 2017). Currently, biodiversity loss can be mainly attributed to (1) changes in land and sea use, (2) unsustainable exploitation of organisms, (3) climate change, (4) pollution (e.g. eutrophication, pesticides, wastes) and (5) invasive species (e.g. Tilman et al. 2001; Meyer and Butaud 2009; Harter et al. 2015; Urban et al. 2016; IPBES 2019). Yet, most of these factors can be directly connected to food production from our modern agriculture (IAASTD 2009; Pingali 2012; Smith et al. 2013; Steffen et al. 2015), which is also responsible for at least $20 \%$ of global anthropogenic GHG emissions (Steinfeld et al. 2006; Schwarzer et al. 2012).

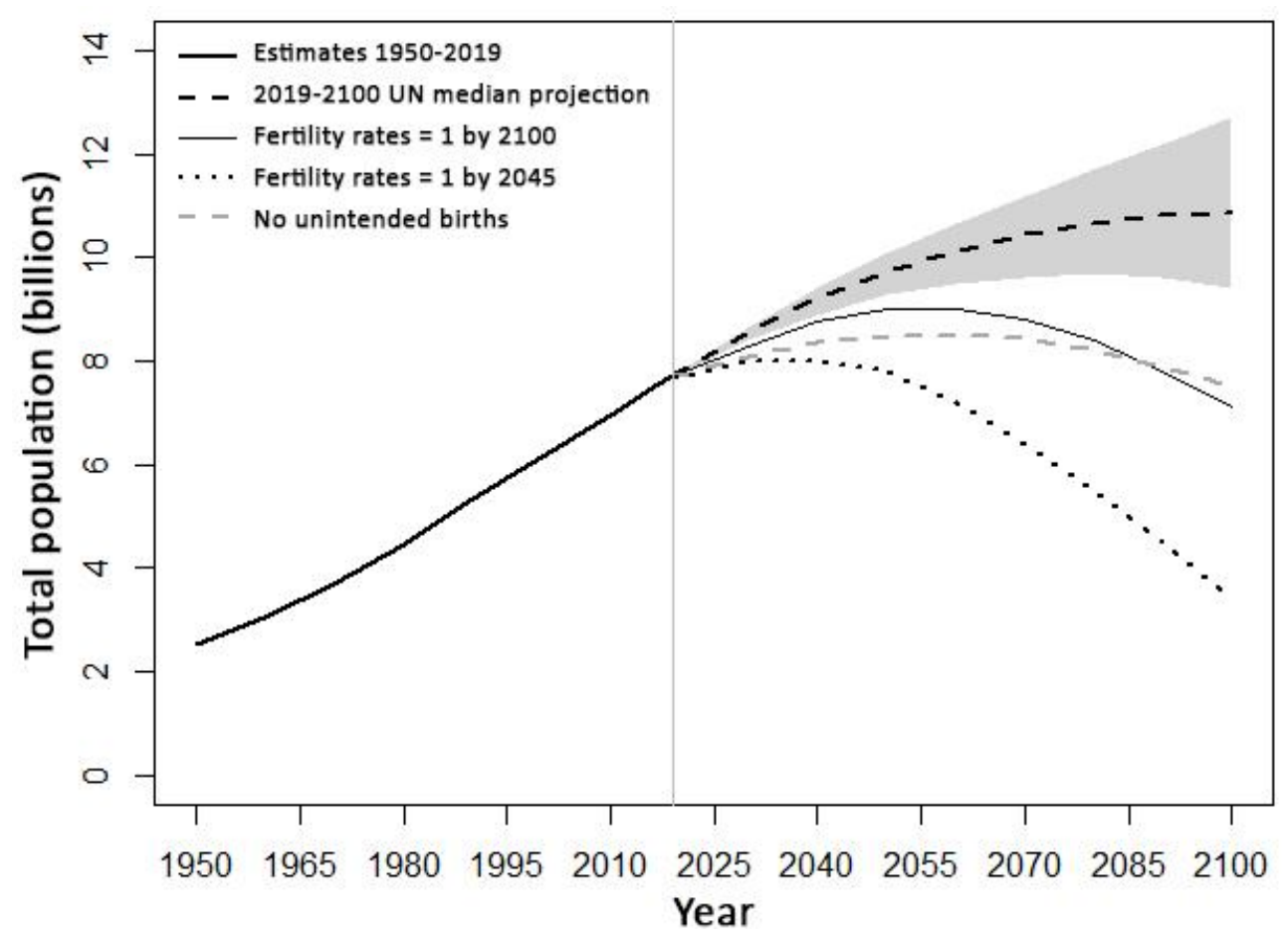

Figure 1: The world population from 1950 to 2019 and projections from 2019 to 2100 based on the United Nations median scenario (United Nations 2019) with its corresponding 95\% confidence interval (grey area), and three of the scenarios reported by Bradshaw and Brook (2014). In the first scenario, world fertility rates progressively decrease to reach 1 children per woman by 2100 . In the second scenario, the world fertility rates 
are reduced to 1 by 2045 . Global population projection from the third scenario only includes avoidance of unintended births (see Bradshaw and Brook 2014 for details).

The continuous conversion of lands for crop and animal agriculture is a well-known cause of habitat destruction (Mora and Zapata 2013; Maxwell et al. 2016; Estrada et al. 2017). For example, over the past century more than half of species-rich wetlands have been drained worldwide, mostly to be converted to agriculture production (Meyer and Turner 1992; MEA 2005). Another classic example of species-rich habitat destruction is the deforestation occurring in the tropics, with a rate of 5.5 million ha/year between 2010 and 2015 (Keenan et al. 2015), mostly caused by agriculture for the expansion of plantations (e.g. soy, oil palm) and ranches (Geist and Lambin 2002; Gibbs et al. 2010; Lewis et al. 2015; Vijay et al. 2016). Although preserving healthy forests, and other natural ecosystems, is urgently needed to address both biodiversity loss and climate change issues (Bonan 2008; Malhi et al. 2008; IPCC 2018), the demand for cropland production over natural areas keeps increasing by around 3.4 million ha/year due to the world's growing human population and consumption patterns (FAOSTAT 2009).

The current projections from the United Nations (2019) predict, as a median scenario, a population of 9.7 billion by 2050 and 10.9 billion by 2100 (Fig. 1). Nowadays, concerns even arise about the ability of food production capacity to meet this massive coming demand (Foley et al. 2005; Sheppard 2014; Nelson et al. 2018), as agricultural output will have to increase by at least $50 \%$ by 2050 and double or triple by 2100 (FAO 2009; Clay 2011; Alexandratos and Bruinsma 2012). In response, by 2050 the environmental impacts of food production are also expected to further increase by 50-90\% (Springmann et al. 2018). In such context, it can be questioned whether feeding the world can even be compatible with maintaining global biodiversity (Musters et al. 2000; Newton et al. 2007; Mora and Sale 2011; Henderson and Loreau 2018).

Several scenarios aiming at meeting these two challenging objectives have been proposed, combining solutions such as raising intensification rather than expansion, shifting to organic agriculture, changing diets and reducing food wastes (Foley et al. 2011; Foley 2014, 2015; Aleksandrowicz et al. 2016; Springmann et al. 2016, 2018; Muller et al. 2017; Parodi et al. 2018; Willett et al. 2019). Although this so-called "sustainable intensification" (Baulcombe et al. 2009; Clay 2011) has many valuable ideas, according to Crist et al. (2017) this approach remains largely idealistic as it would have to be implemented expeditiously and globally to account for the increasing demand. Crist et al. (2017) illustrated this point with the example of Chinese soybean imports that increased over the past 2 decades in response to the growing meat consumption in the country. Based on the 
present trends, it has been estimated that, by 2024, the current soybean production of Brazil, Argentina and the United States combined will not be enough to meet Chinese demand (Hansen and Gale 2014; Maverick 2014). In this context, it is hard to imagine how this demand, from only one developing country, can be met without conversion of more forests and other natural lands.

Consequently, although calling for a "sustainable intensification" is laudable, as stated by Crist et al. (2017): "its reasoning is flawed in two ways: (1) in its apparent acceptance of the current massive impact of food production as a roughly acceptable baseline impact for supporting humans - one among Earth's millions of species; and (2) in encouraging an impression among scientists, policymakers, and the public that Earth can provide for an additional 2 to 4 billion people without escalating biodiversity destruction - an implausible idealization when trends are tallied". Yet, this should not rule out the fact that many people, especially in developed countries, should eat less meat and reduce food wastes while improving technologies of production, and advocacy on that front is an undeniable necessity. However, as noted by Springmann et al. (2018), "no single measure is enough to keep environmental impacts of food production within all planetary boundaries simultaneously". Therefore, considering the current trends pointing inevitably towards increasing consumption of fish, dairy, egg and meat, limiting human population growth offers another solution to reduce the impacts of food production.

Along with food production, the increasing consumption of energy and materials is also threatening Earth's biodiversity and climate. Over the last centuries, improvements in materials and technologies have contributed to our modern lifestyle but have also led to significant increases in energy consumption, currently $80 \%$ delivered by fossil fuels (International Energy Agency 2015). The development of the internet over the last decades has also significantly increased this energy demand (Bolla et al. 2011), with no foreseeable reduction due to the continuously increasing use of data in people's everyday life for services such as online shopping, electronic mailing, social media (e.g. Facebook, Instagram), music (e.g. Spotify, Deezer) or video (e.g. Youtube, Netflix), among others. As an example, Mora et al. (2018a) recently projected that the use of Bitcoin, an online investment and payment system, could alone produce enough GHG emissions to push warming above $2{ }^{\circ} \mathrm{C}$ within less than three decades. This comes with, worldwide, increasing global use of energy in various other services such as heat, transportation and industrial processes (Olah et al. 2011; USDE 2015). Based on current trends, total energy consumption is set to continue to rise at least until 2100 in response to growing human population and increasing per-capita incomes, especially in the developing world (Nakicenovic and Swart 2000; Clarke et al. 2007; Steckel et al. 2013). 
Since inexpensive and abundant energy remains crucial for economic development (Heard et al. 2017), there seems little prospect of decreasing energy consumption from cheap fossil fuels. Over the last decades, to answer this increasing demand, environmentally damaging unconventional fossil fuels (e.g. tar sands, shale gas, coalseam gas) even began to be extracted (Wigley 2011). Yet, considering the necessity to reduce global GHG emissions from fossil sources while answering the growing energy demands, several scenarios have been proposed using 100\% renewable electricity (e.g. Jacobson and Delucchi 2011; Teske et al. 2012; Mason et al. 2013; Jacobson et al. 2015; Connolly et al. 2016; Singer et al. 2017). On the other hand, a recent review reported that most of these scenarios relied on unrealistic forecasts of global energy demand and that, to date, turning completely to renewable electricity worldwide seems largely idealistic considering the increasing global need for energy (Heard et al. 2017). Although such conclusions are arguable, it is likely that no single solution is enough to address energy-related environmental impacts and that trade-offs are inevitable. Therefore, advocacy is undeniably needed towards limiting as much as possible the global per-capita consumption of energy while improving technologies. Considering that foreseeable trends point inevitably towards a continuously increasing energy consumption, limiting human population growth offers another solution to slow down this demand.

Finally, whatever the food and energy system used, a remaining obvious aspect inherent to an increasing population is the simple need of land for basic human facilities (e.g. houses, roads, shops, schools, hospitals), which will inevitably be taken to the detriment of natural lands. After agriculture, urban growth is already regarded as one of the main causes of habitat destruction (Gibbs et al. 2010; Lewis et al. 2015; Vijay et al. 2016). For sure, the conflict for space between humans and the natural world remains one of the key conservation issues to address, especially considering that current protected areas are regarded as not enough to prevent biodiversity loss (Laurance et al. 2012). Addressing this issue will require sufficient amount of suitable habitat (up to $50 \%$ of lands and seas) to be protected in order to ensure the livelihood of other species (Noss et al. 2012; Wilson 2016; Cafaro et al. 2017; Dinerstein et al. 2017). It has been estimated that facilitating well-being for both nature and humanity requires a sustainable human population ranging between 1.5 and 5 billion people, depending on percapita levels of consumption (Lowe 2016). Daily et al. (1994) even estimated as optimum a global population of no more than 2 billion for ensuring high-quality life to all people, while sustaining a globally interconnected civilization and protecting large natural areas. Although such estimations may underemphasize potential improvements in technologies, it is likely that addressing both biodiversity loss and climate change issues will be impossible without considering human population growth as part of the equation. 


\section{Changing perceptions about the population question}

For a long time the population question has been strongly denied or ignored by much of society (Washington 2013, 2015), and many reasons have been proposed to explain why (Kopnina and Washington 2016). Among others, the declining global mean fertility rate, which reduced from 5.2 in 1950 to 2.5 currently (United Nations 2019), has promoted a widespread perception that the population problem was essentially solved (Pearce 2008; Crist et al. 2017). Yet, more than 50\% of the world's population still lives in areas where fertility rates are higher than parental replacement (2.1), and almost $10 \%$ where they exceed 5, leading population projections to at least triple by 2100 in almost 50 developing countries (United Nations 2019). Moreover, some recent studies have reported that fertility reduction has stalled in most sub-Saharan African countries (Cleland 2009; Mayhew and Colbourn 2015; Guillebaud 2016). From 1.2 billion people today, Africa is expected to reach between 3 and 6 billion people by 2100 (United Nations 2019), which suggests that the population question is not completely on the way to solving itself.

In addition, in some developed countries, the combination of low fertility rates with an ageing population has raised concerns about the effects that a shrinking workforce may have on standards of living and public finances (Lee and Mason 2014; Crist et al. 2017). Therefore, in practice many countries still assume that population growth is favourable in order to stimulate economic growth in terms of markets and consumers (Blowfield 2013; Kopnina and Washington 2016). This also comes with the generally accepted concept, perhaps derived from 2 million years of human evolution, that more people has always been a good thing for society, which was true until the last century (Washington 1991). Moreover, the general lack of agreement about the population question in the scientific community has also probably contributed to neglecting the population issues (Sinding 2000; Sayre 2008).

Also another aspect to consider is the concept of "inexorable demographic momentum" - the fatalistic idea that nothing can be done to address the population question over the short-term (Bradshaw and Brook 2014). This is underpinned by the combination of current low mortality rates and a high number of young people (born when fertility rates were higher), that are now of an age to start their family and will inevitably lead to another 1-2 billion population increase in the next 30 years, even with low fertility rates (Fig. 1, United Nations 2019). In any cases, whether reducing human population growth may or may not be a quick answer to the environmental problems (cf. critics and debate: Bradshaw and Brook 2015; O'Sullivan 2015), any attempt could importantly reduce the risk of climate catastrophe and biodiversity loss over the long-term (Spears 2015). Indeed, any action 
taken now could lead to a difference of several billion fewer people by 2100 (United Nations 2019), and the long-term nature of this result should not inhibit productive discussions around the population question.

Denials of the population issue also arise from the debate as to whether it is increasing population or excessive consumption that underlies humanity's impact, especially since the emergence of the climate change issue which directed attention towards developed countries overconsumption problems (Crist et al. 2017). For many people, overpopulation is still seen as a non-issue, or the wrong issue, and overconsumption is the only problem (Ellis 2013; Fletcher et al. 2014). Therefore, those critics usually argue that addressing human population growth leads to social and economic segregation, with overpopulation concerns seen as being "racist", "anti-poor", "antideveloping countries" or even "anti-human" (as discussed by Kopnina and Washington 2016). These arguments refer to the dichotomy classically established between developed countries and developing countries, where population concerns are seen as only a developing world issue and overconsumption as only a developed world problem. Yet, it is now necessary to move beyond this prevailing binary approach to overcome obstacles to a productive discussion about these global problems.

Firstly, it has been already reported that human impacts on earth and its ecosystems are caused by the total population and its continued growth, both in numbers and in consumption of resources, so neither can be ignored (Ehrlich and Ehrlich 2014). In addition, arguments characterising overconsumption as only a developed world problem are becoming outmoded as the developing world (e.g. China, Brazil, India) is now rapidly increasing its use of resources and energy (Washington 2015). For example, China has become the world's largest GHG emitter, far above the United States and the European Union (World Resources Institute 2014). The last decades have also seen a massive increase in developing countries' middle class. As a consequence, the global middle class reached a total of 3.2 billion people in 2016 and is expected to further increase to about 5 billion by 2030 (Ravallion 2009; Kharas 2017), which will necessarily contribute to the escalation in consumption. Obviously, this argument is not aimed at blaming the developing countries, as all humans deserve equal opportunities for well-being, health and basic necessities, but it highlights that overconsumption is no longer a developed world issue only.

In the same way, the population question is more complex than just a developing world problem. In 2014, while promoting access to contraception in the context of lowering global GHG emissions, the IPCC stated that "this is important not only in poor countries but also some rich ones like the United States, where there is unmet need for reproductive health services as well as high GHG emissions per capita” (Smith et al. 2014). In the United States, 
it has been estimated that each child adds about 9441 tons of $\mathrm{CO}_{2}$ to the carbon legacy of an average woman, which corresponds to 5.7 times her lifetime emissions (Murtaugh and Schlax 2009). In this context, although substantial efforts must be done to reduce population growth in developing countries, having one fewer child in a developed country can also significantly contribute to lower humanity's global impact (Wynes and Nicholas 2017). In any case, human overpopulation and overconsumption are two complex and interconnected issues that need to be addressed at the same time, in both developing and developed countries.

Other serious factors that contributed to neglecting the population question are religious and cultural influences. The role played by religions such as the Catholic Church has been important to global population growth, especially in poor developing countries in South America, Africa or South-east Asia. Promoting conservative ideas relating to procreation and the sacredness of human life has led, among other things, to the religious prohibition of modern birth control methods in many countries (Cleland 2009). In addition to the religious aspect, in some countries there is cultural and familial pro-natalism, where having a large number of children is seen as a status symbol (Kopnina and Washington 2016).

Finally, a major reason explaining why the population question is so often ignored or denied is because it questions the most fundamental right of any human being: giving life. As noted by Kopnina and Washington (2016), "Clearly people love babies, so it goes against the grain to say we should have fewer." This point could be illustrated by an example that happened in France in 2018, after the "Agence France-Presse" transmitted the conclusion from Wynes and Nicholas (2017) that having one fewer child is the most effective individual action to reduce annual personal GHG emissions. Many people were shocked by this statement (Chartier 2018), which outlines the real need to bring the population question at the centre of the public discussion and raise awareness about the reality of the situation. This reticence may partly stem from the erroneous belief that human numbers cannot be influenced other than through coercive "population controls" (Halfon 2007), which still inhibits rational discussion about population policies in many countries.

\section{Potential solutions to address environmental issues through population regulation}

It is necessary to move beyond the belief that, as urbanization and economic development encourage smaller families, population growth problems will resolve themselves. Although this might be true, this process is likely to take more than a century (United Nations 2019) while, in the meantime, extending humanity's impact will be necessarily done to the detriment of other species. Yet, over the last century several examples have shown that, even in the absence of strong economic development, non-coercive population policies can efficiently reduce 
fertility (Prata 2009; Engelman 2016a). Some countries such as Iran, Colombia, Brazil, Cuba, Thailand, Tunisia and Bangladesh, have managed to halve their fertility rates in about the same time as China, but without a coercive one child policy (Brown 2011; Campbell et al. 2013; Guillebaud 2016). Several non-coercive strategies, mostly based on access to contraception and education, have been proposed by Engelman (2016a) to tackle population growth worldwide and contribute to addressing environmental issues, as discussed hereafter.

Providing access to modern contraception and family planning services everywhere is one of the major challenges of the next decades if we are to slow population growth (Cates et al. 2010; Bongaarts 2016). For 2012, it has been estimated that $40 \%$ (i.e. about 85 million) of all pregnancies in the world were unintended (Sedgh et al. 2014; Singh et al. 2014). This proportion - even higher in developed countries with 47\% (i.e. about 11 million) than in developing countries with $39 \%$ (i.e. about 74 million) - shows that millions of women (with no distinction between countries) need better access to contraception in order to avoid pregnancy. Therefore, promoting such policies would greatly empower women through the basic human right to have children by choice (Guillebaud 2016). Demographic analyses have demonstrated that, if women could time their pregnancies according to their own desires, fertility rates would decline, allowing a population peak below 9 billion people by 2050 with a subsequent slow decrease (Fig. 1, Engelman 2011; Cafaro and Crist 2012). Over the last 50 years, the international community has invested around $\$ 400$ billion in the 20 least developed countries that have the highest birth rates, of which less than $1 \%$ went to birth control (Wu 2013). Yet, it has been estimated that "only" \$9.4 billion would be needed annually to provide modern contraceptive services for women expressing a need for it (Singh et al. 2014) ), which is relatively small compared with what is spent on defence worldwide for example.

Ensuring education is also another major strategy to move the world swiftly towards a smaller population. Crist et al. (2017) illustrated this point based on African statistics where, without any education, women have, on average, 5.4 children, while this number drops to 4.3, 2.7 and 2.2 children for women who complete primary school, secondary school and those who go to college respectively (Engelman 2016b). Although impressive progress has been made over the last decades, further efforts are needed in many countries, especially to fill the gap in education between boys and girls (World Bank 2011). Therefore, achieving full gender equality in education would significantly lower global fertility rates and ultimately lead to a decreasing population (Eder et al. 2015). Sexual education also needs to be offered for all students as its lack constitutes another major obstacle to the prevention of unintended pregnancies. Nowadays, even in developed countries, many young people are ignorant of how their body works and are not fully aware of contraceptive options to prevent pregnancies. This 
education also offers good opportunities to teach how important it is to respect the bodies and sexual intentions of others and, if necessary, how to abstain from unwanted sex (Kaidbey and Engelman 2017).

In addition, although pro-natalist government policies may have not always significantly raised fertility rates, considering that the environment and its resources do not increase with increasing population, rewarding parents financially for each additional child goes against any ecological logic. Instead of rewarding the number of children, Engelman (2016a) proposed only rewarding parenthood status itself, through a fixed benefit for all parents. Therefore, this solution would allow couples to decide for themselves whether another child would make sense economically, considering that there would be no further benefits. Obviously, this strategy also requires that access to contraceptive options is available and socially acceptable.

A problem inherent to lower fertility rates and a decreasing population is that countries will move through a period where the effects of an ageing population could lead to serious challenges for healthcare programs and public pensions (Ezeh et al. 2012). Yet, since reaching a lower population is an undeniable necessity, it is preferable to face these challenges directly rather than trying to delay it through pro-natalist policies (Götmark et al. 2018). Several solutions are possible to address these challenges (Smeeding 2014) but will necessarily require many social adjustments such as extending retirement age or raising taxes. In any case, an ageing population will be a relatively short-term phenomenon compared with the long-lasting effects of the ongoing population growth (Sanderson and Scherbov 2010).

Another major challenge is also to raise global awareness about population, environment, and development relationships. Nowadays, because many people spend their lives in densely populated cities, they are disconnected from the natural world and especially how it is impacted by human numbers and human development. Restoring nature at the centre of the people's concerns is required so they can be more sensitive to the impacts of our growing population and overconsumption and why both need to be slowed down. This also offers opportunities for potential changes in worldview and ethics, towards ecocentrism as well as ecological ethics and ecological justice (Curry 2011; Washington et al. 2018). Currently, the predominant worldview in human societies - anthropocentrism - only sees nature as a resource for human use (Crist 2012). In contrast, in an ecocentric worldview all natural entities (i.e. human and non-human organisms, ecosystems and ecosystem processes) are understood to have intrinsic value and worthy of respect (Batavia et al. 2017; Washington et al. 2017; Washington 2018). Therefore, changing to a worldview acknowledging that nature has a right to exist for 
itself and not just for human use is also likely to be required for addressing both overpopulation and overconsumption.

Finally, limiting population growth worldwide would be easier if political leaders are involved and can interact with each other. This aspect is crucial as the question of the human impacts on the environment goes far beyond any country borders and needs to be addressed globally. Questions of both overconsumption and overpopulation need to be considered everywhere, with no distinction between developed and developing countries. It is very likely that this century will witness movements of people in response to environmental degradation and the effects of climate change (Crist et al. 2017). As an example, while the current immigration from Africa and middle-East is seen as a "crisis" in Europe, it is unclear how it will be possible to answer such demand when the population in these developing countries (and the corresponding pressure on the environment) will triple. Yet, it has been reported that, by promoting strategies for lowering population growth in countries with high fertility rates, the resulting environmental and economic benefits should counter pressure on people to emigrate (Bloom 2000). It is therefore very important that leaders can plan an agenda for international cooperation towards global objectives of sustainability.

\section{Conclusion}

It is undeniable that the size of the human population is not the only factor impacting Earth and its ecosystems. Yet, the research reviewed in this paper highlights that continuing human population growth plays a substantial role in biodiversity loss and climate change, and this role urgently needs more attention in scientific, policy and public circles (Mora 2014; Engelman et al. 2016). As stated by Kopnina and Washington (2016), "Denying the problem of a growing population - whose appetites, material aspirations, and life expectancy have greatly increased in the recent decades - seems detrimental to any long-term objective of achieving sustainability". It seems that part of the debate around the population question arises from the assumption that talking about population growth shifts the attention away from the excessive consumption issue. Therefore, a first step is to end this debate about what really underlies humanity's environmental impact: both unsustainable population and excessive consumption are part of the equation and must be addressed concurrently in developing and developed countries. This review clearly highlights that there is no easy solution to our environmental problems. Therefore they need to be addressed on every possible front.

Undeniably, addressing excessive consumption is urgently required worldwide, including actions such as shifting away from fossil fuels while improving efficiency gains in materials and energy; reducing production 
and consumption of ecologically costly foods (e.g. animal products); drastically reducing pollution, wastes (including food wastes) and the production of throwaway and rapidly obsolescing products; and advancing recycling while reducing extractive industries (Crist et al. 2017; Ripple et al. 2017). At the same time, protecting biodiversity also calls for considerable expansion of effective marine and terrestrial protected areas in order to ensure the survival of all species. Finally, discussing the population question should no longer be a taboo, as population policies, through a framework of human rights, constitute another substantial way to lower humanity's impact on Earth, therefore protecting biodiversity while increasing human welfare. This could also open discussions about worldview and ethics, and the need to commit to ecocentric conservation that acknowledges the intrinsic value of nature.

This paper is of course not aimed at blaming people having children in developing or developed countries, but only to raise awareness about what impact a person's reproductive choice may have on the environment. In this way, this discussion supports recent studies (e.g. Guillebaud 2016; Kopnina and Washington 2016; Crist et al. 2017; Gil Pérez and Vilches 2017) and invites a productive and reasoned dialogue about the population question, and more generally about the place of humans in the natural world. Implementing population policies could allow reducing the global population to about 6-7 billion by 2100 and to a sustainable 2-3 billion by the end of the following century (Staples and Cafaro 2012). The non-coercive measures reported in this review promote access to contraception, family planning services and, most importantly, education in order to empower women through the basic human right to make their own choice about when, and how many children they have. Such measures also call for improvements in gender equality worldwide, which has also proven to be generally beneficial to nature (Cook et al. 2019). Although there are political, religious or cultural barriers to advancing the status of women in many countries, such barriers could be overcome through education in both the media and schools (Rawe et al. 2012; Guillebaud 2016).

In any case, any attempt is preferable than doing nothing and, for addressing both excessive consumption and increasing population, education seems to be a key factor. Since the last century, humanity has widely promoted a quantity growth over a quality growth in many fields (e.g. food, materials, technologies), but it is now time to reverse this trend and start to apply a new rule based on "fewer but better". This could also, in a way, be transposed to human population growth - where, assuming an ecological logic, it would globally be better to raise fewer but more educated children (Lowe 2016). New generations urgently need to be more sensitive to questions such as reducing waste, protecting biodiversity, and promoting the development of values about 
nature, equity and sustainability. In this context, although many people often wonder what kind of planet we are leaving to our children, it is now also crucial to wonder what kind of children we are leaving to our planet.

\title{
Acknowledgements
}

I am particularly grateful to Mark Bloomberg (University of Canterbury, New Zealand), Philip Cafaro (Colorado State University, USA) and two anonymous reviewers for giving useful comments on an earlier version of the manuscript. I also record my appreciation to Alexandre Alaman, Maxime Remazeilles and Pierre Marc for constructive discussions about the topics of overpopulation and sustainability that greatly helped me in writing this paper.

\author{
Abbreviations \\ COP: Conference of the Parties \\ GHG: Greenhouse gas \\ IPCC: International Panel on Climate Change
}

\section{References}

Abel GJ, Barakat B, Samir KC, Lutz W (2016) Meeting the Sustainable Development Goals leads to lower world population growth. Proceedings of the National Academy of Sciences, 113(50):14294-14299. http://doi.org/10.1073/pnas. 1611386113

Aleksandrowicz L, Green R, Joy EJ, Smith P, Haines A (2016) The impacts of dietary change on greenhouse gas emissions, land use, water use, and health: a systematic review. PloS one, 11(11):e0165797. http://doi.org/10.1371/journal.pone.0165797

Alexandratos N, Bruinsma J (2012) World Agriculture Towards 2030/2050: The 2012 Revision. Food and Agriculture Organization of the United Nations, Rome, Italy.

Baillie JEM, Cokeliss Z (2004) Extinctions in recent time. In 2004 IUCN Red List of Threatened Species: A Global Species Assessment, Baillie JEM, Hilton-Taylor C, Stuart SN (Eds). IUCN, Gland, Switzerland and Cambridge, UK, pp. 33-50. 
Batavia C, Nelson MP (2017) For goodness sake! What is intrinsic value and why should we care?. Biological Conservation, 209:366-376. https://doi.org/10.1016/j.biocon.2017.03.003

Baulcombe D, Crute I, Davies B, Dunwell J, Gale M, Jones J, Pretty J, Sutherland W, Toulmin C (2009) Reaping the benefits: science and the sustainable intensification of global agriculture. The Royal Society. https://royalsociety.org/topics-policy/publications/2009/reaping-benefits/

Berry T (2000) The Great Work: Our way into the future. Bell Tower, New York, New York, USA.

Bloom DE, Canning D, Malaney PN (2000) Population dynamics and economic growth in Asia. Population and Development Review, 26:257-290. https://www.jstor.org/stable/3115219

Blowfield M (2013) Business and sustainability. Oxford University Press, Oxford, UK.

Bolla R, Bruschi R, Davoli F, Cucchietti F (2011) Energy efficiency in the future internet: A survey of existing approaches and trends in energy-aware fixed network infrastructures. IEEE Communications Surveys and Tutorials, 13(2):223-244. http://doi.org/10.1109/SURV.2011.071410.00073

Bonan GB (2008) Forests and climate change: forcings, feedbacks, and the climate benefits of forests. Science, 320(5882):1444-1449. http://doi.org/10.1126/science.1155121

Bongaarts J (2016) Development: Slow down population growth. Nature, 530(7591):409-413.

Bradshaw CJ, Brook BW (2015) Reply to O’Neill et al. and O’Sullivan: Fertility reduction will help, but only in the long term. Proceedings of the National Academy of Sciences, 112(6):E508-E509. https://doi.org/10.1073/pnas.1423102112

Bradshaw CJ, Brook BW (2014) Human population reduction is not a quick fix for environmental problems. Proceedings of the National Academy of Sciences, 111(46):16610-16615. https://doi.org/10.1073/pnas.1410465111

Brown L (2011) World on the edge: how to prevent environmental and economic collapse. W.W. Norton and Co, New York, NY, USA.

Burke KD, Williams JW, Chandler MA, Haywood AM, Lunt DJ, Otto-Bliesner BL (2018) Pliocene and Eocene provide best analogs for near-future climates. Proceedings of the National Academy of Sciences. https://doi.org/10.1073/pnas.1809600115 
Cafaro P, Butler T, Crist E, Cryer P, Dinerstein E, Kopnina H, Noss R, Piccolo J, Taylor B, Vynne C, Washington $\mathrm{H}$ (2017) If we want a whole Earth, Nature Needs Half: a response to Büscher et al. Oryx, 51(3):400-400. https://doi.org/10.1017/S0030605317000072

Cafaro P, Crist E (2012) Life on the brink: environmentalists confront overpopulation, Cafaro P, Crist E (Eds). University of Georgia Press, USA.

Cahill AE, Aiello-Lammens ME, Fisher-Reid MC, Hua X, Karanewsky CJ, Yeong Ryu H, Sbeglia GC, Spagnolo F, Waldron JB, Warsi O, Wiens JJ. (2013) How does climate change cause extinction? Proceedings of the Royal Society B: Biological Sciences, 280(1750):20121890. http://dx.doi.org/10.1098/rspb.2012.1890

Campbell MM, Prata N, Potts M (2013) The impact of freedom on fertility decline. Journal of family planning and reproductive health care, 39:44-50. http://dx.doi.org/10.1136/jfprhc-2012-100405

Cates W, Karim QA, El-Sadr W, Haffner DW, Kalema-Zikusoka G, Rogo K, Petruney T, Averitt MD (2010) Family planning and the millennium development goals. Science, 329(5999):1603-1603. https://doi.org/10.1126/science.1197080

CBD (2010) Aichi Biodiversity Targets. Convention on Biological diversity. https://www.cbd.int/sp/targets/

Ceballos G, Ehrlich AD, Barnosky A, García RM, Pringle TM, Palmer (2015) Accelerated modern humaninduced species losses: Entering the sixth mass extinction. Science Advances. 1:e1400253. https://doi.org/10.1126/sciadv.1400253

Ceballos G, Ehrlich PR, Dirzo R (2017) Biological annihilation via the ongoing sixth mass extinction signaled by vertebrate population losses and declines. Proceedings of the National Academy of Sciences, 114(30):E6089E6096. http://dx.doi.org/10.1073/pnas.1704949114

Ceballos G, García A, Ehrlich PR (2010) The sixth extinction crisis: loss of animal populations and species. Journal of Cosmology, 8(1821):1821-1831. http://journalofcosmology.com/ClimateChange100.html

Chartier S (2018) Faut-il faire moins d'enfants pour sauver la planète? La vie. http://www.lavie.fr/actualite/ecologie/faut-il-faire-moins-d-enfants-pour-sauver-la-planete-12-10-201893643_8.php 
Chertow MR (2000) The IPAT equation and its variants. Journal of industrial ecology, 4(4):13-29. https://doi.org/10.1162/10881980052541927

Clarke L, Edmonds J, Jacoby H, Pitcher H, Reilly J, Richels R (2007) Scenarios of greenhouse gas emissions and atmospheric concentrations. Department of Energy, Office of Biological and Environmental Research, Washington DC, USA.

Clay J (2011) Freeze the footprint of food. Nature, 475(7356):287-289. https://doi.org/10.1038/475287a

Cleland J (2009) Contraception in historical and global perspective. Best Practice and Research Clinical Obstetrics and Gynaecology, 23(2):165-176. https://doi.org/10.1016/j.bpobgyn.2008.11.002

Connolly D, Lund H, Mathiesen BV (2016) Smart Energy Europe: The technical and economic impact of one potential $100 \%$ renewable energy scenario for the European Union. Renewable and Sustainable Energy Reviews, 60:1634-1653. https://doi.org/10.1016/j.rser.2016.02.025

Cook NJ, Grillos T, Andersson KP (2019) Gender quotas increase the equality and effectiveness of climate policy interventions. Nature Climate Change, 9:330-334.

Crist E (2012) Abundant Earth and the population question. In Life on the Brink: Environmentalists Confront Overpopulation, Cafaro P, Crist E (Eds). University of Georgia Press, Georgia, USA, pp. 141-151.

Crist E, Mora C, Engelman R (2017) The interaction of human population, food production, and biodiversity protection. Science 356 (6335), 260-264. http://doi.org/10.1126/science.aal2011

Curry P (2011) Ecological Ethics: An Introduction, Second edition. Polity Press, Cambridge, UK.

Custer S, DiLorenzo M, Masaki T, Sethi T, Harutyunyan A (2018) Listening to Leaders 2018: Is development cooperation tuned-in or tone-deaf?. AidData at William and Mary, Williamsburg, VA, USA.

Daily GC (1999) Developing a scientific basis for managing Earth's life support systems. Conservation Ecology, 3(2):14. http://www.consecol.org/vol3/iss2/art14/

Daily GC, Ehrlich AH, Ehrlich PR (1994) Optimum human population size. Population and environment, 15(6):469-475. https://doi.org/10.1007/BF02211719 
Daily GC, Polasky S, Goldstein J, Kareiva PM, Mooney HA, Pejchar L, Ricketts TH, Salzam J,Shallenberger R (2009) Ecosystem services in decision making: time to deliver. Frontiers in Ecology and the Environment, 7(1):21-28. https://doi.org/10.1890/080025

Díaz S, Pascual U, Stenseke M, Martín-López B, Watson RT, Molnár Z, et al. (2018) Assessing nature's contributions to people. Science, 359(6373):270-272. https://doi.org/10.1126/science.aap8826

Dietz R, O’Neill D (2013) Enough is enough: building a sustainable economy in a world of finite resources. Berrett-Koehler Publishers, San Francisco, CA, USA.

Dinerstein E, Olson D, Joshi A, Vynne C, Burgess ND, Wikramanayake E, et al. (2017) An ecoregion-based approach to protecting half the terrestrial realm. BioScience, 67(6):534-545. https://doi.org/10.1093/biosci/bix014

Eder J, Goujon A, Haplichnik TKCS, Lutz W, Potančokova M (2015) Global Human Capital Data Sheet 2015. Wittgenstein Centre for Demography and Global Human Capital, Vienna, Austria.

Ehrlich PR, Ehrlich AH (2014) It's the numbers, stupid!. In Sustainable futures: Linking population, resources and the environment, Goldie J, Betts K (EDS). CSIRO Publishing, Canberra, Australia.

Ehrlich PR, Holdren JP (1971) Impact of population growth. Science, 171(3977):1212-1217. https://www.jstor.org/stable/1731166

Ehrlich PR, Holdren JP (1972) A bulletin dialogue on the 'Closing Circle': Critique: One dimensional ecology. Bulletin of the Atomic Scientists, 28(5):16-27. https://doi.org/10.1080/00963402.1972.11457930

Ellis EC (2013) Overpopulation is not the problem. The New York Times. http://www.nytimes.com/2013/09/14/opinion/overpopulation-isnot-the-problem.html?_r=0

Engelman R (2016a) Nine population strategies to stop short of 9 billion. In A Future Beyond Growth, Washington H, Twomey P (Eds). Routledge, pp. 56-66.

Engelman R (2016b) Africa's population will soar dangerously unless women are more empowered. Scientific American. www.scientificamerican.com/article/africa-s-population-will-soar-dangerously-unlesswomen-aremore-empowered/. 
Engelman R (2011) An end to population growth: Why family planning is key to a sustainable future, solutions for a sustainable and desirable future, 2(3):32-41. http://www.thesolutionsjournal.com/node/919

Engelman R, Terefe YG, Markham V (2016) Family Planning and Environmental Sustainability: Assessing the Science. Wordwatch Institute.

Estrada A, Garber PA, Rylands AB, Roos C, Fernandez-Duque E, Di Fiore A, et al. (2017) Impending extinction crisis of the world's primates: Why primates matter. Science Advances, 3(1):e1600946. https://doi.org/10.1126/sciadv.1600946

Ezeh AC, Bongaarts J, Mberu B (2012) Global population trends and policy options. The Lancet, 380(9837):142-148. https://doi.org/10.1016/S0140-6736(12)60696-5

FAO (2009) How to Feed the World: Global Agriculture Towards 2050. Food and Agriculture Organization of the United Nations, Rome, Italy. www.fao.org/fileadmin/templates/wsfs/docs/Issues_ papers/HLEF2050_Global_Agriculture.pdf.

FAO (2019) The State of the World's Biodiversity for Food and Agriculture (J. Bélanger and D. Pilling (eds.)). Food and Agriculture Organization of the United Nations, Commission on Genetic Resources for Food and Agriculture Assessments, Rome, Italy. 572 pp.

FAOSTAT (2009) Statistical databases. Food and Agriculture Organization of the United Nations, Rome, Italy.

Fletcher R, Breitlin J, Puleo V (2014) Barbarian hordes: the overpopulation scapegoat in international development $\quad$ discourse. Third $\quad$ World $\quad$ Quarterly, $\quad$ 35(7):1195-1215. https://doi.org/10.1080/01436597.2014.926110

Foley JA (2015) Can we feed the world and sustain the planet?. Scientific American, 24:84-89. https://www.scientificamerican.com/article/5-steps-to-feed-the-world-and-sustain-the-planet/

Foley JA (2014) A five-step plan to feed the world. National Geographic, 225(5):26-58.

Foley JA, DeFries R, Asner GP, Barford C, Bonan G, Carpenter SR, et al. (2005) Global consequences of land use. science, 309(5734):570-574. https://doi.org/10.1126/science.1111772

Foley JA, Ramankutty N, Brauman KA, Cassidy ES, Gerber JS, Johnston M, et al. (2011) Solutions for a cultivated planet. Nature, 478(7369):337442. https://doi.org/10.1038/nature10452 
Geist HJ, Lambin EF (2002) Proximate Causes and Underlying Driving Forces of Tropical Deforestation: Tropical forests are disappearing as the result of many pressures, both local and regional, acting in various combinations in different geographical locations. BioScience, 52(2):143-150. https://doi.org/10.1641/00063568(2002)052[0143:PCAUDF]2.0.CO;2

GFW (2018) 2017 was the second-worst year on record for tropical tree cover loss. Global Forest Watch. https://blog.globalforestwatch.org/data/2017-was-the-second-worst-year-on-record-for-tropical-tree-coverloss?utm_campaign=gfw\&utm_source=wriinsights\&utm_medium=hyperlink\&utm_term=gfwclimatebythenumb ers_10_2018

Gibbs HK, Ruesch AS, Achard F, Clayton MK, Holmgren P, Ramankutty N, Foley JA (2010) Tropical forests were the primary sources of new agricultural land in the 1980s and 1990s. Proceedings of the National Academy of Sciences, 107(38):16732-16737. https://doi.org/10.1073/pnas.0910275107

Gil Pérez D, Vilches A (2017) El olvido de la demografía en los estudios de Sostenibilidad. Ápice. Revista de Educación Científica, 1(2):1-17. https://doi.org/10.17979/arec.2017.1.2.3074

Götmark F, Cafaro P, O’Sullivan J (2018) Aging human populations: good for us, good for the Earth. Trends in Ecology and Evolution, 33(11):851-862. https://doi.org/10.1016/j.tree.2018.08.015

Guillebaud J (2016) Voluntary family planning to minimise and mitigate climate change. bmj, 353:i2102. https://doi.org/10.1136/bmj.i2102

Halfon S (2007) The Cairo consensus: demographic surveys, women's empowerment, and regime change in population policy. Lexington Books.

Hallmann CA, Sorg M, Jongejans E, Siepel H, Hofland N, Schwan H, et al. (2017) More than 75 percent decline over 27 years in total flying insect biomass in protected areas. PloS one, 12(10):e0185809. https://doi.org/10.1371/journal.pone.0185809

Hansen J, Gale F (2014) China in the next decade: Rising meat demand and growing imports of feed. Amber Waves, 7. www.ers.usda.gov/amber-waves/2014/april/china-in-thenext- decade-rising-meat-demand-andgrowing-imports-of-feed/. 
Hansen J, Kharecha P, Sato M, Masson-Delmotte V, Ackerman F, Beerling DJ, et al. (2013) Assessing "dangerous climate change": required reduction of carbon emissions to protect young people, future generations and nature. PloS one, 8(12), e81648. https://doi.org/10.1371/journal.pone.0081648

Harter DE, Irl SD, Seo B, Steinbauer MJ, Gillespie R, Triantis KA, et al. (2015) Impacts of global climate change on the floras of oceanic islands-Projections, implications and current knowledge. Perspectives in Plant Ecology, Evolution and Systematics, 17(2):160-183. https://doi.org/10.1016/j.ppees.2015.01.003

Heard BP, Brook BW, Wigley TMI, Bradshaw CJA (2017) Burden of proof: A comprehensive review of the feasibility of $100 \%$ renewable-electricity systems. Renewable and Sustainable Energy Reviews, 76:1122-1133. http://doi.org/10.1016/j.rser.2017.03.114

Henderson K, Loreau M (2018) How ecological feedbacks between human population and land cover influence sustainability. PLoS Comput Biol 14(8):e1006389. https://doi.org/10.1371/journal.pcbi.1006389

Hulme M (2009) Why we disagree about climate change: understanding controversy, inaction and opportunity. Cambridge University Press, Cambridge, UK.

Huntingford C, Zelazowski P, Galbraith D, Mercado LM, Sitch S, Fisher R, et al. (2013) Simulated resilience of tropical rainforests to CO2-induced climate change. Nature Geoscience, 6(4):268-273. https://doi.org/10.1038/ngeo1741

IAASTD (2009) Agriculture at a Crossroads: The Global Report. Island Press, Washington DC, USA.

International Energy Agency (2015) Key World Energy Statistics. OECD/ IEA, Paris, France.

INPE (2018) INPE estimated $7900 \mathrm{~km}^{2}$ of shallow cut deforestation in the Amazon in 2018. http://www.inpe.br/noticias/noticia.php?Cod_Noticia=4957

IPBES (2018) Biodiversity and Nature's Contributions Continue Dangerous Decline, Scientists Warn. Intergovernmental Science-Policy Platform on Biodiversity and Ecosystem Services (IPBES). Media release. https://www.ipbes.net/news/media-release-updated-biodiversity-nature\%E2\%80\%99s-contributions-continuedangerous-decline-scientists\#_ftn1

IPBES (2019) Global assessment report on biodiversity and ecosystem services of the Intergovernmental Science-Policy Platform on Biodiversity and Ecosystem Services. 
IPCC (2012) Managing the Risks of Extreme Events and Disasters to Advance Climate Change Adaptation: A Special Report of Working Groups I and II of the Intergovernmental Panel on Climate Change. Cambridge University Press, Cambridge, UK.

IPCC (2013) Climate Change 2013: The Physical Science Basis: Working Groups I Contribution to the Fifth Assessment Report of the Intergovernmental Panel on Climate Change. Cambridge University Press, Cambridge, UK.

IPCC (2018) Global warming of $1.5^{\circ} \mathrm{C}$. An IPCC Special Report on the impacts of global warming of $1.5^{\circ} \mathrm{C}$ above pre-industrial levels and related global greenhouse gas emission pathways, in the context of strengthening the global response to the threat of climate change, sustainable development, and efforts to eradicate poverty. Masson-Delmotte V, Zhai P, Pörtner HO, Roberts D, Skea J, Shukla PR, Pirani A, et al. (Eds). World Meteorological Organization, Geneva, Switzerland.

IUCN (2018) The IUCN Red List of Threatened Species, Version 2018 (IUCN, 2018); http://www. iucnredlist.org

Jacobson MZ, Delucchi MA (2011) Providing all global energy with wind, water, and solar power, Part I: Technologies, energy resources, quantities and areas of infrastructure, and materials. Energy policy, 39(3):11541169. https://doi.org/10.1016/j.enpol.2010.11.040

Jacobson MZ, Delucchi MA, Cameron MA, Frew BA (2015) Low-cost solution to the grid reliability problem with $100 \%$ penetration of intermittent wind, water, and solar for all purposes. Proceedings of the National Academy of Sciences, 112(49):15060-15065. https://doi.org/10.1073/pnas.1510028112

Kaidbey M, Engelman R (2017) Our Bodies, Our Future: Expanding Comprehensive Sexuality Education. In EarthEd: Rethinking Education on a Changing Planet. Island Press, Washington, DC. pp. 179-189.

Keenan RJ, Reams GA, Achard F, de Freitas JV, Grainger A, Lindquist E (2015) Dynamics of global forest area: Results from the FAO Global Forest Resources Assessment 2015. Forest Ecology and Management, 352:9-20. https://doi.org/10.1016/j.foreco.2015.06.014

Kemp L (2017) Limiting the climate impact of the Trump administration. Palgrave Communications, $3(1): 9$. https://doi.org/10.1057/s41599-017-0003-6 
Kharas H (2017) The Unprecedented Expansion of the Global Middle Class: An Update. Brookings Global Economy and Development. www.brookings.edu/wp-content/uploads/2017/02/global_20170228_global-middleclass.pdf.

Klein Goldewijk K, Beusen A, Van Drecht G, De Vos M (2011) The HYDE 3.1 spatially explicit database of human-induced global land-use change over the past 12,000 years. Global Ecology and Biogeography, 20(1):7386. https://doi.org/10.1111/j.1466-8238.2010.00587.x

Kopnina H, Washington H (2016) Discussing why population growth is still ignored or denied. Chinese journal of population resources and environment, 14(2):133-143. http://dx.doi.org/10.1080/10042857.2016.1149296

Laurance WF, Useche DC, Rendeiro J, Kalka M, Bradshaw CJ, Sloan SP, et al. (2012) Averting biodiversity collapse in tropical forest protected areas. Nature, 489:290-294. https://doi.org/10.1038/nature11318

Laybourn-Langton L, Rankin L and Baxter D (2019) This is a crisis: Facing up to the age of environmental breakdown, IPPR. http://www.ippr.org/research/publications/age-of-environmental-breakdown

Lister BC, Garcia A (2018) Climate-driven declines in arthropod abundance restructure a rainforest food web. Proceedings of the National Academy of Sciences, 115(44):E10397-E10406. https://doi.org/10.1073/pnas.1722477115

Lee R, Mason A (2014) Is low fertility really a problem? Population aging, dependency, and consumption. Science, 346(6206):229-234. https://doi.org/10.1126/science.1250542

Le Quéré C, Andreaw RM, Friedlingstein P, Sitch S, Hauck J, Pongratz J, Pickers PA et al. (2018) Global carbon budget 2018. Earth system science data, 10:1-54. http://dx.doi.org/10.5194/essd-10-2141-2018.

Lewis SL, Edwards DP, Galbraith D (2015) Increasing human dominance of tropical forests. Science, 349(6250):827-832. https://doi.org/10.1126/science.aaa9932

Lowe I (2016). Population. Better not bigger. In A future beyond growth: Towards a steady state economy, Washington H, Twomey P (Eds). Routledge, pp. 21-31.

Malhi Y, Roberts JT, Betts RA, Killeen TJ, Li W, Nobre CA (2008) Climate change, deforestation, and the fate of the Amazon. Science, 319(5860):169-172. https://doi.org/10.1126/science.1146961 
Malthus TR (1798) An essay on the principle of population as it affects the future improvement of society with remarks on the speculations of Mr. Godwin, M. Condorcet, and other writers.

Mason IG, Page SC, Williamson AG (2013) Security of supply, energy spillage control and peaking options within a $100 \%$ renewable electricity system for New Zealand. Energy Policy, 60:324-33. https://doi.org/10.1016/j.enpol.2013.05.032

Maverick T (2014) China's hunger for soy to exceed global supply. Wall Street Daily. www.wallstreetdaily. com/2014/11/11/china-soybean-futures/.

Maxwell SL, Fuller RA, Brooks TM, Watson JE (2016) Biodiversity: The ravages of guns, nets and bulldozers. Nature, 536(7615):143-145.

Mayhew SH, Colbourn T (2015) Population growth. In Thinking beyond sectors for sustainable development, Waage J, Yap C (Eds). Ubiquity Press, pp 37-44.

MEA (2005) Ecosystems and Human Well-Being: Biodiversity Synthesis. Millennium Ecosystem Assessment. World Resources Institute, Washington DC, USA. www.millenniumassessment.org/documents/ document.354.aspx.pdf.

Meffe GK (1994) Human population control: the missing awareness. Conservation Biology, 8(1):310-313. https://doi.org/10.1046/j.1523-1739.1994.08010310.x

Meyer J-Y, Butaud J-F (2009) The impacts of rats on the endangered native flora of French Polynesia (Pacific Islands): drivers of plant extinction or coup de grâce species? Biological Invasions, 11:1569-1585. https://doi.org/10.1007/s10530-008-9407-y

Meyer WB, Turner BL (1992) Human population growth and global land-use/cover change. Annual Review of Ecology and Systematics, 23(1):39-61. https://doi.org/10.1146/annurev.es.23.110192.000351

MNHN (2018) Le printemps 2018 s'annonce silencieux dans les campagnes françaises. Muséum National d'Histoire Naturelle. https://www.mnhn.fr/fr/recherche-expertise/actualites/printemps-2018-s-annoncesilencieux-campagnes-francaises. 
Mora C (2014) Revisiting the environmental and socioeconomic effects of population growth: a fundamental but fading issue in modern scientific, public, and political circles. Ecology and Society, 19(1). https://www.jstor.org/stable/26269513

Mora C, Rollins RL, Taladay K, Kantar MB, Chock MK, Shimada M, Franklin EC (2018a) Bitcoin emissions alone could push global warming above $2^{\circ} \mathrm{C}$. Nature Climate Change, 8(11):931. https://doi.org/10.1038/s41558$018-0321-8$

Mora C, Sale PF (2011) Ongoing global biodiversity loss and the need to move beyond protected areas: a review of the technical and practical shortcomings of protected areas on land and sea. Marine ecology progress series, 434:251-266. https://doi.org/10.3354/meps09214

Mora C, Spirandelli D, Franklin EC, Lynham J, Kantar MB, Miles W, Smith CZ, Freel K, Moy J, Louis LV, Barba EW, Bettinger K, Frazier AG, Colburn JF, Hanasaki N, Hawkins E, Hirabayashi Y, Knorr W, Little CM, Emanuel K, Sheffield J, Patz JA, Hunter CL (2018b) Broad threat to humanity from cumulative climate hazards intensified by greenhouse gas emissions. Nature Climate Change. https://doi.org/10.1038/s41558-018-0315-6

Mora C, Zapata FA (2013) 17 Anthropogenic footprints on biodiversity. In The Balance of Nature and Human Impact, Krohde K (Ed). Cambridge University Press, Cambridge, UK, pp. 239-257.

Moritz C, Agudo R (2013) The Future of Species Under Climate Change: Resilience or Decline? Science, 341:504-508. https://doi.org/10.1126/science. 1237190

Muller A, Schader C, El-Hage Scialabba N, Brüggemann J, Isensee A, Erb K-H, Smith P, Klocke P, Leiber F, Stolze M, Niggli U (2017) Strategies for feeding the world more sustainably with organic agriculture. Nature Communication, 8:1290. https://doi.org/10.1038/s41467-017-01410-w

Murtaugh PA, Schlax MG (2009) Reproduction and the carbon legacies of individuals. Global Environmental Change, 19(1):14-20. https://doi.org/10.1016/j.gloenvcha.2008.10.007

Musters CJM, De Graaf HJ, Ter Keurs WJ (2000) Can protected areas be expanded in Africa?. Science, 287(5459):1759-1760. https://doi.org/10.1126/science.287.5459.1759

Nakicenovic N, Swart R (2000) Emissions scenarios. Special report of the Intergovernmental panel on climate change. Cambridge, UK. 
Nelson G, Bogard J, Lividini K, Arsenault J, Riley M, Sulser TB et al. (2018) Income growth and climate change effects on global nutrition security to mid-century. Nature Sustainability, 1(12):773-781. https://doi.org/10.1038/s41893-018-0192-z

Newton K, Cote IM, Pilling GM, Jennings S, Dulvy NK (2007) Current and future sustainability of island coral reef fisheries. Current Biology, 17(7):655-658. https://doi.org/10.1016/j.cub.2007.02.054

Noss RF, Dobson AP, Baldwin R, Beier P, Davis CR, Dellasala DA, et al. (2012) Bolder thinking for conservation. Conservation Biology, 26(1):1-4. https://doi.org/10.1111/j.1523-1739.2011.01738.x

Olah GA, Goeppert A, Prakash GS (2011) Beyond oil and gas: the methanol economy. John Wiley and Sons, Weinheim, Germany.

O’Sullivan JN (2015) Population stabilization potential and its benefits underestimated. Proceedings of the National Academy of Sciences, 112(6):E507-E507. https://doi.org/10.1073/pnas.1422507112

Parodi A, Leip A, De Boer IJM, Slegers PM, Ziegler F, Temme EHM, et al. (2018) The potential of future foods for sustainable and healthy diets. Nature Sustainability, 1(12):782. https://doi.org/10.1038/s41893-018-0189-7

Pearce F (2008) Has the population bomb been defused? Yale School of Forestry and Environmental Studies, Yale, USA. http://e360.yale. edu/feature/the_population_bomb_has_it_been_defused/2042/.

Pingali PL (2012) Green revolution: impacts, limits, and the path ahead. Proceedings of the National Academy of Sciences, 109(31):12302-12308. https://doi.org/10.1073/pnas.0912953109

Pinheiro HT, Teixeira JB, Francini-Filho RB, Soares-Gomes A, Ferreira CEL, Rocha LA (2018) Hope and doubt for the world's marine ecosystems. Perspectives in Ecology and Conservation. https://doi.org/10.1016/j.pecon.2018.11.001

Potts M (2009) Where next?. Philosophical Transactions of the Royal Society B: Biological Sciences, 364:31153124. https://doi.org/10.1098/rstb.2009.0181

Prata N (2009) Making family planning accessible in resource-poor settings. Philosophical Transactions of the Royal Society of London B: Biological Sciences, 364(1532):3093-3099. https://doi.org/10.1098/rstb.2009.0172 
Raupach MR, Marland G, Ciais P, Le Quéré C, Canadell JG, Klepper G, Field CB (2007) Global and regional drivers of accelerating CO2 emissions. Proceedings of the National Academy of Sciences, 104(24):10288-10293. https://doi.org/10.1073/pnas.0700609104

Ravallion M (2009) The developing world's bulging (but vulnerable) "middle class". The World Bank.

Raven P, Chase J, Pires J (2011) Introduction to special issue on biodiversity. American Journal of Botany, 98(3):333-335. https://doi.org/10.3732/ajb.1100055

Rawe K, Dunford A, Stewart J, Espey J, Stoeckel J (2012) Save the Children. Every woman's right. www.savethechildren.org.uk/sites/default/files/docs/Every-Woman-Right-low-res-2.pdf.

Ripple WJ, Smith P, Haberl H, Montzka SA, McAlpine C, Boucher DH. 2014. Ruminants, climate change and climate policy. Nature Climate Change, 4:2-5. https://doi.org/10.1038/ nclimate2081

Ripple WJ, Wolf C, Newsome TM, Galetti M, Alamgir M, Crist E, Mahmoud MI, Laurance WF, et al. (2017)

World Scientists' Warning to Humanity: A Second Notice. Bioscience, 67(12):1026-1028. https://doi.org/10.1093/biosci/bix125

Sánchez-Bayo F, Wyckhuys KA (2019) Worldwide decline of the entomofauna: A review of its drivers. Biological Conservation, 232:8-27. https://doi.org/10.1016/j.biocon.2019.01.020

Sanderson W, Scherbov S (2010) Remeasuring aging. Science, 329:1287-1288. https://doi.org/10.1126/science. 1193647

Sayre NF (2008) The genesis, history, and limits of carrying capacity. Annals of the Association of American Geographers, 98(1):120-134. https://doi.org/10.1080/00045600701734356

Sedgh G, Singh S, Hussain R (2014) Intended and unintended pregnancies worldwide in 2012 and recent trends. Studies in family planning, 45(3):301-314. https://doi.org/10.1111/j.1728-4465.2014.00393.x

Shao W (2018) Can 2018's extreme weather convince skeptics that the climate is changing?. The Washington post. $\quad$ https://www.washingtonpost.com/news/monkey-cage/wp/2018/12/07/can-2018s-extreme-weatherpersuade-skeptics-that-the-climate-is-changing/?noredirect=on\&utm_term=.bc680a640c89

Sheppard C (2014) Famines, food insecurity and coral reef 'Ponzi'fisheries. Marine pollution bulletin, 1(84):1-4. https://doi.org/10.1016/j.marpolbul.2014.04.048 
Sinding SW (2000) The great population debates: How relevant are they for the 21 st century?. American Journal of Public Health, 90(12):1841-1845.

Singer S, Denruyter JP, Yener D (2017) The energy report: 100\% renewable energy by 2050. Towards $100 \%$ Renewable Energy, 379-383.

Singh S, Darroch JE, Ashford LS (2014) Adding it up: The costs and benefits of investing in sexual and reproductive health. Guttmacher Institute, New York, NY, USA.

Smeeding TM (2014) Adjusting to the fertility bust. Science, 346(6206):163-164. https://doi.org/ $10.1126 /$ science. 1260504

Smith P, Haberl H, Popp A, Erb KH, Lauk C, Harper R, et al. (2013) How much land-based greenhouse gas mitigation can be achieved without compromising food security and environmental goals?. Global change biology, 19(8):2285-2302. https://doi.org/10.1111/gcb.12160

Smith KR, Woodward A, Campbell-Lendrum D, et al. (2014) Human health: impacts, adaptation, and cobenefits. Section 11.9.2: access to reproductive health services. In Climate change 2014: impacts adaptation, and vulnerability, Field CB, Barros VR, Dokken DJ, et al. (Eds). Part A: global and sectoral aspects. Cambridge University Press, Cambridge, UK.

Spears D (2015) Smaller human population in 2100 could importantly reduce the risk of climate catastrophe. Proceedings of the National Academy of Sciences, 112(18):E2270-E2270. https://doi.org/10.1073/pnas.1501763112

Springmann M, Godfray HCJ, Rayner M, Scarborough P (2016) Analysis and valuation of the health and climate change cobenefits of dietary change. Proceedings of the National Academy of Sciences, 113(15):4146-4151. https://doi.org/10.1073/pnas.1523119113

Springmann M, Clark M, Mason-D’Croz D, Wiebe K, Bodirsky BL, Lassaletta L, et al. (2018) Options for keeping the food system within environmental limits. Nature, 562:519-525. https://doi.org/10.1038/s41586-0180594-0

Staples W, Cafaro P. 2012. For a species right to exist. In Life on the brink: environmentalists confront overpopulation, Cafaro P, Crist E (Eds). University of Georgia Press, USA, p. 283-300. 
Steckel JC, Brecha RJ, Jakob M, Strefler J, Luderer G (2013) Development without energy? Assessing future scenarios of energy consumption in developing countries. Ecological Economics, 90:53-67. https://doi.org/10.1016/j.ecolecon.2013.02.006

Steffen W, Richardson K, Rockström J, Cornell SE, Fetzer I, Bennett EM, et al. (2015) Planetary boundaries: Guiding human development on a changing planet. Science, 347(6223):1259855. https://doi.org/10.1126/science.1259855

Steinfeld H, Gerber P, Wassenaar T, Castel V, de Haan C (2006) Livestock's Long Shadow: Environmental Issues and Options. Food and Agriculture Organization of the United Nations. www.fao. org/docrep/010/a0701e/a0701e00.HTM

Schwarzer S, Witt R, Zommers A (2012) Growing Greenhouse Gas Emissions Due to Meat Production. Environment Programme of the United Nations. https://na.unep.net/geas/ getuneppagewitharticleidscript.php?article_id=92.

Teske S, Muth J, Sawyer S, Pregger T, Simon S, Naegler T, et al. (2012) Energy [r]evolution. World Energy Scenario, 4th ed.. Amsterdam, Netherlands: Greenpeace: Global Wind Energy Council \& European Renewable Energy Council; 2012. [16] Lund H, Mathiesen BV. Energy system analysis of 100\% renewable

Thomas CD, Cameron A, Green RE, Bakkenes M, Beaumont LJ, Collingham YC, et al. (2004) Extinction risk from climate change. Nature, 427(6970):145-148. https://doi.org/10.1038/nature02121

Tilman D, Fargione J, Wolff B, D'antonio C, Dobson A, Howarth R, Schindler D, Schlesinger WH, Simberloff D, Swackhamer D (2001) Forecasting agriculturally driven global environmental change. Science, 292(5515):281-284. https://doi.org/10.1126/science.1057544

United Nations (2019) World Population Prospects 2019: Highlights (ST/ESA/SER.A/423). Department of Economic and Social Affairs, Population Division.

UNCED (1992) Declaration of the UN Conference on Environment and Development. In Report of the United Nations Conference on Environment and Development. Rio de Janiero, Brazil.

UNEP (2018) The Emissions Gap Report 2018. United Nations Environment Programme, Nairobi.

UNFCCC (2015) Adoption of the Paris agreement. United Nations Office, Geneva, Switzerland. 
Urban MC (2015) Accelerating extinction risk from climate change. Science 348 (6234):571-573. https://doi.org/10.1126/science.aaa4984

Urban MC, Bocedi G, Hendry AP, Mihoub JB, Pe'er G, Singer A, et al. (2016) Improving the forecast for biodiversity under climate change. Science, 353(6304):aad8466. https://doi.org/10.1126/science.aad8466

USDE (2015) TA 61: Industrial Process Heating Systems. Quadrennial Technology Review. U.S. Department of Energy. Washington DC, USA.

USGCRP (2018) Impacts, risks, and adaptation in the United States: Fourth National Climate Assessment, Volume II: Report-in-Brief, Reidmiller DR, Avery CW, Easterling DR, Kunkel KE, Lewis KLM, Maycock TK, Stewart BC (Eds). U.S. Global Change Research Program, Washington, DC, USA.

Vijay V, Pimm SL, Jenkins CN, Smith SJ (2016) The Impacts of Oil Palm on Recent Deforestation and Biodiversity Loss. PLoS one 11 (7):e0159668. https://doi.org/10.1371/journal.pone.0159668

Washington H (2018) A Sense of Wonder Towards Nature: Healing the Planet Through Belonging. Routledge, London, UK. https://doi.org/10.4324/9780429490910

Washington H. (2015) Demystifying sustainability: towards real solutions. Routledge, London, UK.

Washington H (2013) Human dependence on nature: how to help solve the environmental crisis. Earthscan, London, UK.

Washington H (1991) Ecosolutions: solving environmental problems for the world and Australia. Tea Gardens: Boobook Publications.

Washington H, Chapron G, Kopnina H, Curry P, Gray J, Piccolo JJ (2018) Foregrounding ecojustice in conservation. Biological Conservation, 228:367-374. https://doi.org/10.1016/j.biocon.2018.09.011

Washington H, Taylor B, Kopnina H, Cryer P, Piccolo JJ (2017) Why ecocentrism is the key pathway to sustainability. Ecological Citizen, 1:Y-Z.

Watson JE, Venter O, Lee J, Jones KR, Robinson JG, Possingham HP, Allan JR (2018) Protect the last of the wild. Nature 563:27-30. 
Wigley TML (2011) Coal to gas: The influence of methane leakage. Climatic Change, 108:601-608. https://doi.org/10.1007/s10584-011-0217-3

Willett W, Rockström J, Loken B, Springmann M, Lang T, et al. (2019) Food in the Anthropocene: the EATLancet Commission on healthy diets from sustainable food systems. The Lancet Commissions. http://dx.doi.org/10.1016/S0140-6736(18)31788-4

Wilson EO (2016) Half-earth: our planet's fight for life. WW Norton and Company.

World Bank (2011) Getting to Equal: Promoting Gender Equality through Human Development. World Bank, Washington, DC, USA.

World Resources Institute (2014) Climate Analysis Indicators Tool (CAIT) Version 2.0. World Resources Institute, Washington DC, USA.

$\mathrm{Wu}$ Y (2013) More aid + more people does not equate to less poverty. www.populationmatters.org/documents/aid_people.pdf

WWF (2018) Living Planet Report - 2018: Aiming Higher. Grooten M, Almond REA (Eds). WWF, Gland, Switzerland.

Wynes S, Nicholas KA (2017) The climate mitigation gap: education and government recommendations miss the most effective individual actions. Environmental Research Letters, 12(7):074024.. https://doi.org/10.1088/17489326/aa7541 